UNITED STATES

DEPARTMENT OF THE INTERIOR

GEOLOGICAL SURVEY

POTASSIUM-ARGON AGES OF BASEMENT ROCKS FROM ST. GEORGE ISLAND. ALASKA
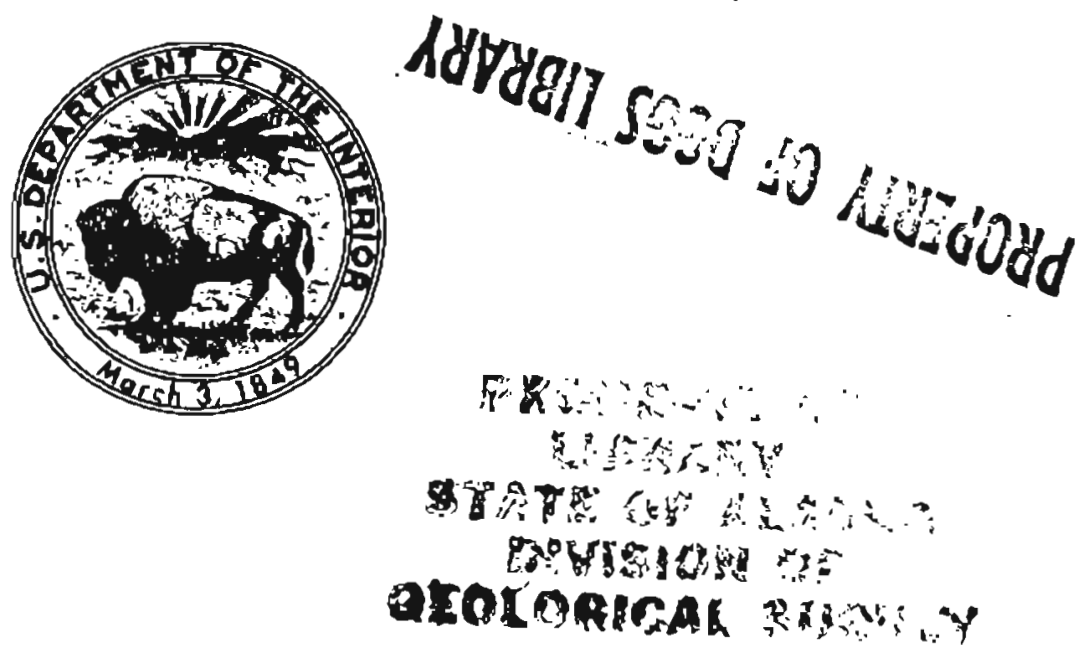

OPEN-FILE REPORT 76-733

This report is preliminary and hat not been edited or reviewed for conformity with Geolonical Survey standands and nomenciature

Menlo Park, California

Ocrober 1976 
POTASSIUM-ARGON AGES OF BASEMENT ROCKS FROM ST. GEORGE ISLAND, ALASKA

$$
\text { by }
$$

M. L. Silberman and D. M. Hopkins

U.S. Geological Survey

345 Middlefield Road

Menlo Park, California

Introduction

St. George Island is one of the Pribilof Islands which lie between $56^{\circ} 35^{\prime}$ and $57^{\circ} 11^{\prime} \mathrm{N}$. lat. in the Bering Sea, $350 \mathrm{~km}$ north of the Aleutian chain. The islands are situated near the margin of the continental platform that underlies most of the northern half of the Bering Sea (fig. 1).

Figure I near here

The Islands are made up mostly of olivine basalt and basanite flows, pillow breccias, pyroclastic deposits, sills and dikes, most of which are nepheline normative (Barth, 1956). The volcanic rocks are late Pliocene to Holocene In age (Cox and others, 1966; D. M. Hopkins and M. L. Silberman, unpub. data) and are interbedded with marine sand and gravel, glacially derived sediments, frost breccia, and windblown sand and silt.

Basement

Serpentinized peridotite crops out for a distance of $5 \mathrm{~km}$ along the southeast shore (fig. 2). In some places, the smoothly planed but

Figure 2 near here

tectonically deformed upper surface is covered by marine sediments and 
then pillow breccia of Pliocene age (fig. 3), but between Garden Cove

Figure 3 near here

and Sea Lion Point, the serpentinized peridotite underlies a glaciated marine terrace of middle Pleistocene age (Hopkins and Einarsson, 1966). North of Garden Cove, the peridotite is intruded by a 400 m-wide composite granitic body refexred to as "aplite" by Barth (1956). Its margin is fine grained and about $3 \mathrm{~m}$ wide and contains alkali feldspar phenocrysts, some biotite, laxgely altered to sericite, and small amounts of garnet. The central portion of the body, which is more basic in composition, is a medium- to fine-grained granular rock, consisting largely of plagioclase, with intergtitial quartz and K-feldspar. Amphibole is present, largely altered to chlorite. In both rocks the feldspars are heavily sericitized. Barth (1956) describes these rocks in greater detail. The granite is younger than the sexpentinized pexidotite, which it intrudes, and older than the alkaline olivine basalts, which unconformably overlie it. The peridotite and the granite are the only outcrops of pre-late Tertiary basement found in the Pribilof Islands.

\section{K-Ar Ages}

Due to alteration and lack of $\mathrm{K}$-bearing minerals, the peridotite is not suitable for $\mathrm{R}-\mathrm{Ar}$ age determination. We collected one sample each from the center and margin of the granitic body. Both samples are altered; the fine-grained margin is sericitized and mafic minerals in the coarser gralned central portion are altered to chlorite. Feldspars in both samples are at least partially sericitized. 
For sample G199, from the margin of the body, an alkali feldspar and a sericite concentrate wexe prepared, and for sample G200, from the coarser grained center, a. K-feldspar and a chlorite mineral concentrate were prepared. Standard heavy liquid and magnetic techniques were used by J. A. Peterson to prepare the purified mineral concentrates. $\mathrm{K}-\mathrm{Ar}$ ages and analytical data for the sarples are listed in table 1.

TABLE I NEAR HERE

\section{Discussion}

The $\mathrm{K}-\mathrm{Ar}$ ages of the samples are not concordant nor are they internally consistent. Table 2 lists the statistical probability levels of differences among the various minerals from the two samples of the granite. Probability levels for age differences exceed one standard deviation (68 percent) for all but two possible combinations of the numbers (table 2).

TABLE 2 NEAR HERE

As mentioned the rocks are altered to some extent and show evidence of recrystallization. We cannot specify at present whether this is a primary deuteric alteration or whether it is a thermal effect resulting from late Tertiary volcanic activity in the area or some earlier thermal event.

The ages, with one exception, vary inversely with potassium content. similar inconsistencies in ages have been noted in areas where small to moderate amounts of extraneous argon (argon other than that generated by radioactive decay of potassium in place after crystallization) is present in minerals in a rock (MacDougall and others, 1969; Hayatsu and Carmichael, 
Table 1

K-Ar ages of basement rocks from St. George Island, Alaska

$\begin{array}{lllllll}\text { Sample no. } & \text { Mineral } & \mathrm{K}_{2} \mathrm{O}^{1} & \mathrm{Ar}^{*}{ }^{40}(\mathrm{moles} / \mathrm{g})^{2} & \mathrm{Ar}^{40} / \mathrm{Ar}^{40} \sum & \begin{array}{c}\text { Apparent } \\ \text { age (m.y.) }\end{array} \\ \text { G199 } & \begin{array}{l}\text { alkalf } \\ \text { feldspar }\end{array} & 3.15 & 2.532 \times 10^{-10} & 0.57 & 55.0 \pm 2.2 \\ \text { G199 } & \begin{array}{l}\text { serfcfte } \\ \text { concentrate }\end{array} & 3.35 & 2.419 \times 10^{-10} & 0.78 & 49.5 \pm 2.0 \\ \text { G200 } & \text { K-feldspar } & 7.21 & 5.546 \times 10^{-10} & 0.49 & 52.7 \pm 2.1 \\ \text { G200 } & \text { chlorite } & 0.407 & 0.3404 \times 10^{-10} & 0.47 & 57.2 \pm 2.3\end{array}$

'Potasstum was analyzed by flame photometry using a lithium metaborate fusion technique (Ingamelis, 1970), the Tithium serving as an internal standard. Mineral standards were used for calibration. Analysts: M. Cremer, J. H. Christie.

${ }^{2}$ Argon was analyzed by standard isotope dilution-mass spectrometry techniques described by Dalrymple and Lanphere (1969). Ar* represents radiogenic argon. Analyst: M. L. Silberman.

Analytical uncertainty of apparent age estimated at one standard deviation is a combined estimate from uncertainties in the potassium and argon analytical techniques, and is approximately 4 percent.

Constants used in age calculation:

$$
\begin{aligned}
& \lambda_{e}=0.572 \times 10^{-10} \mathrm{yr}^{-1} \\
& \lambda_{e^{1}}=8.78 \times 10^{-13} \mathrm{yr}^{-1} \\
& \lambda_{\beta}=4.963 \times 10^{-10} \mathrm{yr}^{-1} \\
& \mathrm{~K}^{40} / \mathrm{K}_{\text {total }}=1.167 \times 10^{-4} \mathrm{~mole} / \mathrm{mole} .
\end{aligned}
$$


Table 2

Statistical level of probability of age differences, from minerals from felsic dike, St. George Is land

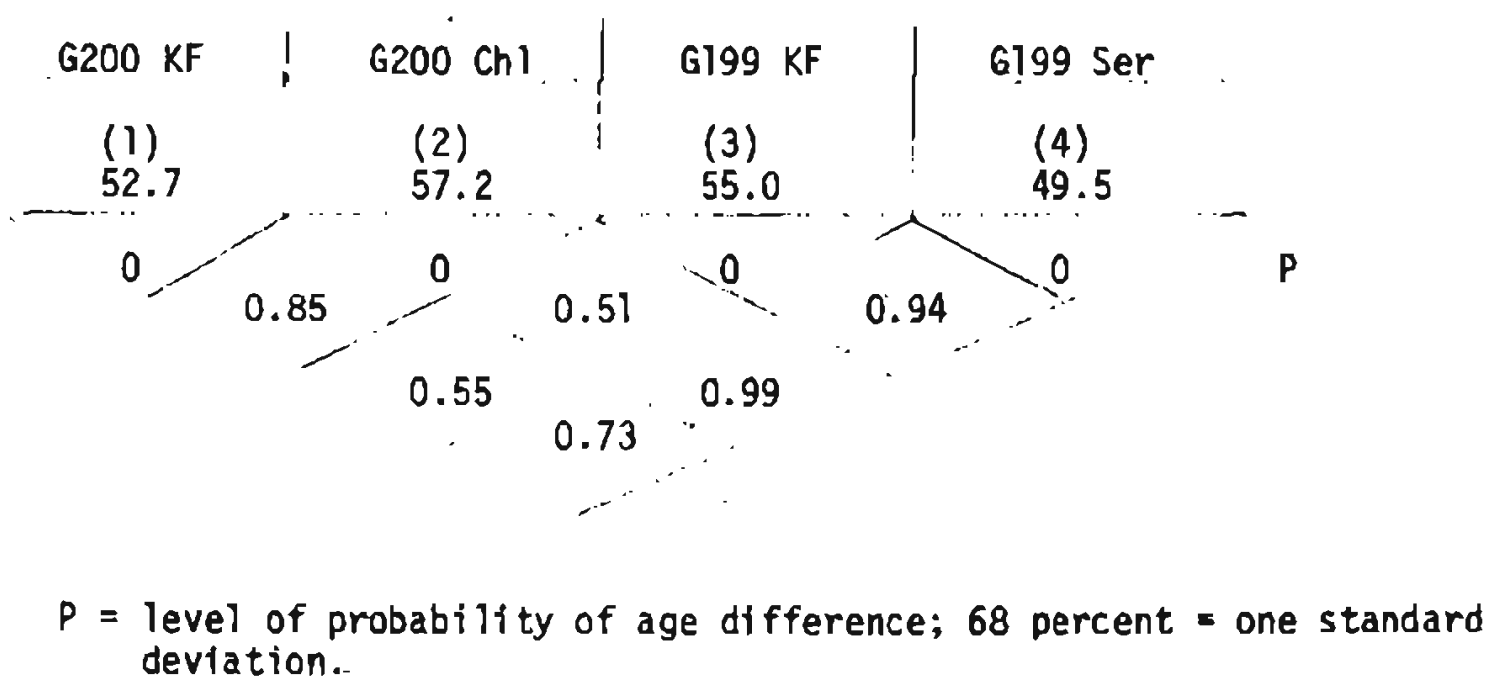


1970; Shafaqullah and Damon, 1974). The effect of extraneous argon is stronger on minerals with low $\mathrm{K}$ content because less radiogenic argon is generated over a given period of time. Thus, the age of the lowest K-bearing mineral in table 1 , the chlorite from sample 6200 , yields the oldest age of the group, which would be expected if the model of excess argon is the correct explanation for the age discrepancies.

Using a technique developed by MacDougall and others (1969) and Hayatsu and Carmichael (1970), it is sometimes possible to obtain an initial or a reset $\mathrm{k}-\mathrm{Ar}$ age (metamorphic age) fron a suite of cogenetic samples that contain excess argon-40, or that have lost argon-40 (Shafaquilah and Damon, 1974). We have plotted the data for argon and potassium content from the minerals on an initial argon diagram (fig.4). The slope in this diagram is proportional to age and the intercept yields the Initial amount of argon present in each mineral in excess of the amount produced by radioactive decay of potassium. In practice, this method has yielded useful metamorphic ages in areas where thermal events have occurred, redistributing the argon among various minerals in a suite of rocks, and where the total system has remained either closed to argon gain or loss (Hayatsu and Carmichael, 1970) or where each sample has gained or lost a constant amount of argon (Shafaqullah and Damon, 1974). Figure 3 shows the plot of points on this diagram. The equation of the best-fit line through the points is: $\operatorname{Ar}^{40}=\operatorname{Ar}_{e}^{40}+K^{40} \frac{{ }_{e}}{\lambda}\left(e^{\lambda T}+1\right)$, where: $\quad A x^{40}=$ total argon-40 less atmospheric argon-40 $A x_{\mathrm{e}}^{40}=$ excess argon-40

$\lambda_{e}$ and $\lambda$ are decay constants for $k^{40}$ $\mathbf{T}=$ Age 
the equation is of the forn $y=m x+b$, where:

$$
\begin{aligned}
& y=A r^{40} \text { measured (corrected for atmospheric argon content) } \\
& \mathrm{b}=\text { initial or excess argon } \\
& \mathrm{x}=\mathrm{K}^{40} \\
& \mathrm{~m}=\frac{\lambda}{\lambda}\left(\mathrm{e}^{\lambda T}+1\right) \text { which can be solved for } \mathrm{T} .
\end{aligned}
$$

From the data:

$$
A x^{40}=3.348 \times 10^{-12}+3.045 \times 10^{-3} x^{40} \text { (in moles). }
$$

The slope yields an isochron age of $51.7 \pm 1.9 \mathrm{m.y}$.

The isochron results suggest a small amount of excess radiogenic argon, on the order of $3 \times 10^{-12}$ moles/g. In all probabllity, this age should be considered a metamorphic or minimum age, rather than the true age of crystalization of the rock. However, due to the small amount of excess argon, the resetting was probably not due to the late Tertiary or Holocene volcanic activity, but was rather due to an earlier thermal event.

\section{Discussion and Conclusions}

Marine geological and geophysical studies indicate that the Pribilof Islands lie near the southern margin of a belt of volcanic and plutonic rocks and minor interbedded continental sediments of Late Cretaceous and Paleocene age (the Okhtosk-Chukotsk volcanic belt of Russian authors) and near the northern margin of a belt of deep-water flysch deposits of Late Cretaceous age (the Roryak-Anadyr flysch belt of Russian authors) (Marlow and others, 1976; Patton and others, 1976). The two belts are separated in Northeast Siberia and southwestern Alaska by a belt $100-500 \mathrm{~km}$ wide consisting of shallow-water and nommarine sedimentary rocks of Late 
Cretaceous and Paleocene-age (Patton-and,others, 1976), but if this belt is present near the Pribilof Islands, it must be very narrow.

On St. Matthew Island, $500 \mathrm{~km}$ north of St. George Island, the Okhotsk-Chukotsk volcanlc belt is represented by calc-alkaline volcanic rocks of basaltic to rhyolitic composition which are intruded and locally metamorphosed by a small granodiorite pluton. The volcanic rocks have yielded K-Ar ages of 65 to $77 \mathrm{~m} . \mathrm{y}$. (Late Cretaceous) and hornblende from the granodiorite has yielded a $\mathrm{k}$-Ar age of $61 \mathrm{~m} \cdot \mathrm{y}$ - (earliest Tertiary) (Fatton and others, 1976). Flysch deposits from the Pribilof canyon have yielded a Maestrictian microfauna (Hopkins and others, 1969), indicating an approximate age of 65 to $68 \mathrm{~m} \cdot \mathrm{y}$.

Scholl and others (1975) confirm earlier inferences that the edge of the continental shelf in the Bering sea formed the boundary between the North American-Northeast Siberian continental plate and the Kula oceanic plate of Grow and Atwater (1970) during much of Mesozoic time. After reviewing the alternatives, they conclude that subduction probably shifted southward from the continental margin to the Aleutian arc-trench system during latest Cretaceous or earliest Tertiary time. We suggest that the serpentinized peridotite on St. George Island marks a subduction zone formed when the North American-Eurasian continental plate was overriding the Kula oceanic plate during Mesozoic time.

Our K-Ar age determinations indicate that the serpentinite on St. George Island was intxuded by a small granitic body only slightly later than (and, since our determinations represent minimum ages, possibly contemporaneously with) intrusive and volcanic activity on st. Matthew Island. 
Thus, we have the seemingly anomalous record of the superposition of a magmatic arc--the Okhotsk-Chukotsk volcanic belt--upon a subduction zone. We suggest that this supexposition is the consequence of the shift in the position of the subduction zone from the continental margin in the Bering Sea to the Aleutian Trench in the North Paciflc Ocean. 


\section{References}

Barth, T. F. W., 1956, Geology and petrology of the Pxibilof Islands, Alaska: U.S. Geol. Survey Bull. 1028-F, P. 101-160.

Cox, A. V., Hopkins, D. M., and Dalrymple, G. B., 1966, Geomagnetic polaxity epochs; Pribilof Islands, Alaska, Geol. Soc. America Bu1l., v. 77, p. $883-920$.

Dalrymple, G. B., and Iranphere, M. A., 1969, Potassium-argon dating:

San Francisco, California, w. H. Freeman and Co., 258 p.

Grow, J. A., and Atwater, T., 1970, M1d-Tertiary tectonic transition

In the Aleutian Arc: Geol. Soc. Amerlca Bull., v. 81, p. 3715-3722.

Hayatsu, A., and Carmichael, C. M., 1970, K-Ar isochron method and inftlal argon ratios: Earth and Planetary Sci. Letters, v. 8, p. $71-76$.

Hopkins, D. M., and Einarsson, Th., 1966, Pleistocene glaciation on St. George, Pribilof Islands: Science, v. 152, p. 343-345.

Hopkins, D. M., Scholl, D. W., Addicott, w. D., and others, 1969, Cretaceous, Tertiary, and early Pleistocene rocks from the continental margin in the Bering Sea: Geol. Soc. America Bull., v. 80, P. 1471-1480.

Ingamells, C. 0., 1970, Lithium metaborate flux in silicate analyses: Anal. Chim. Acta, v. 52, p. 323-334.

MacDougall, Ian, Polach, H. A., and Stipp, J. J., 1969, Excess radiogenic argon in young sub-aerial basalts from the Auckland volcantc field, New Zealand: Geochim. et Cosmochim. Acta, v. 33, p. 1485-1520. 
Marlow, M. S., Scholl, D. W., Cooper, A. K., and Buffington, E. C, , 1976, Structure and evolution of Bering Sea shelf south of st. Lawrence Island: Am. Assoc. Petroleun Geologists Bull., v. 60, no. 2 , p. 161-183.

Patton, W. W., Jr., Lanphere, M. A., Miller, T. P., and Scott, Richard, 1976, Age and tectonic significance of volcanic rocks on $\mathrm{st}$. Matthew Island, Bering Sea, Alaska: U.S. Geol. Survey Jour. Research, v. 4, P. 67-73.

Scholl, D. W., Buffington, E. C., and Marlow, M. S., 1975, Plate tectonics and the structural evolution of the Aleutian-Bering Sea region, in Forbes, R. B., ed., The geophysics and geology of the Berlng Sea region: Geol. Soc. Aruerica Spec. Paper 151, p. $1-32$.

Shafaqullah, M., and Damon, P. E., 1974, Evaluation of K-Ar isochron methods: Geochim. et Cosmochim. Acta, v. 38, p. 1341-1358.

York, D., 1969, Least squares fltting of a straight line with correlated errors: Earth and Planetary Sci. Letters, v. 5, p. $320-324$. 


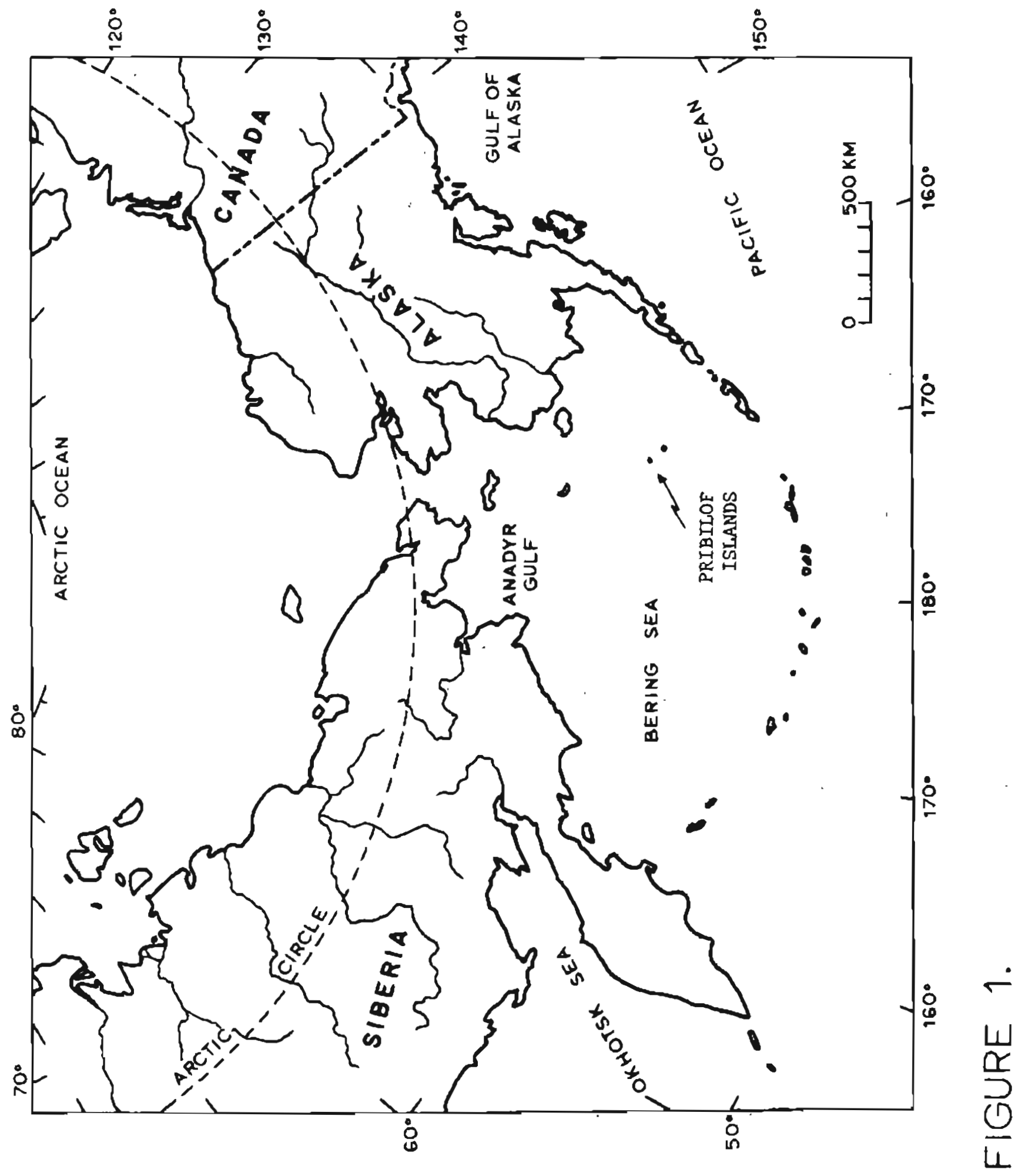




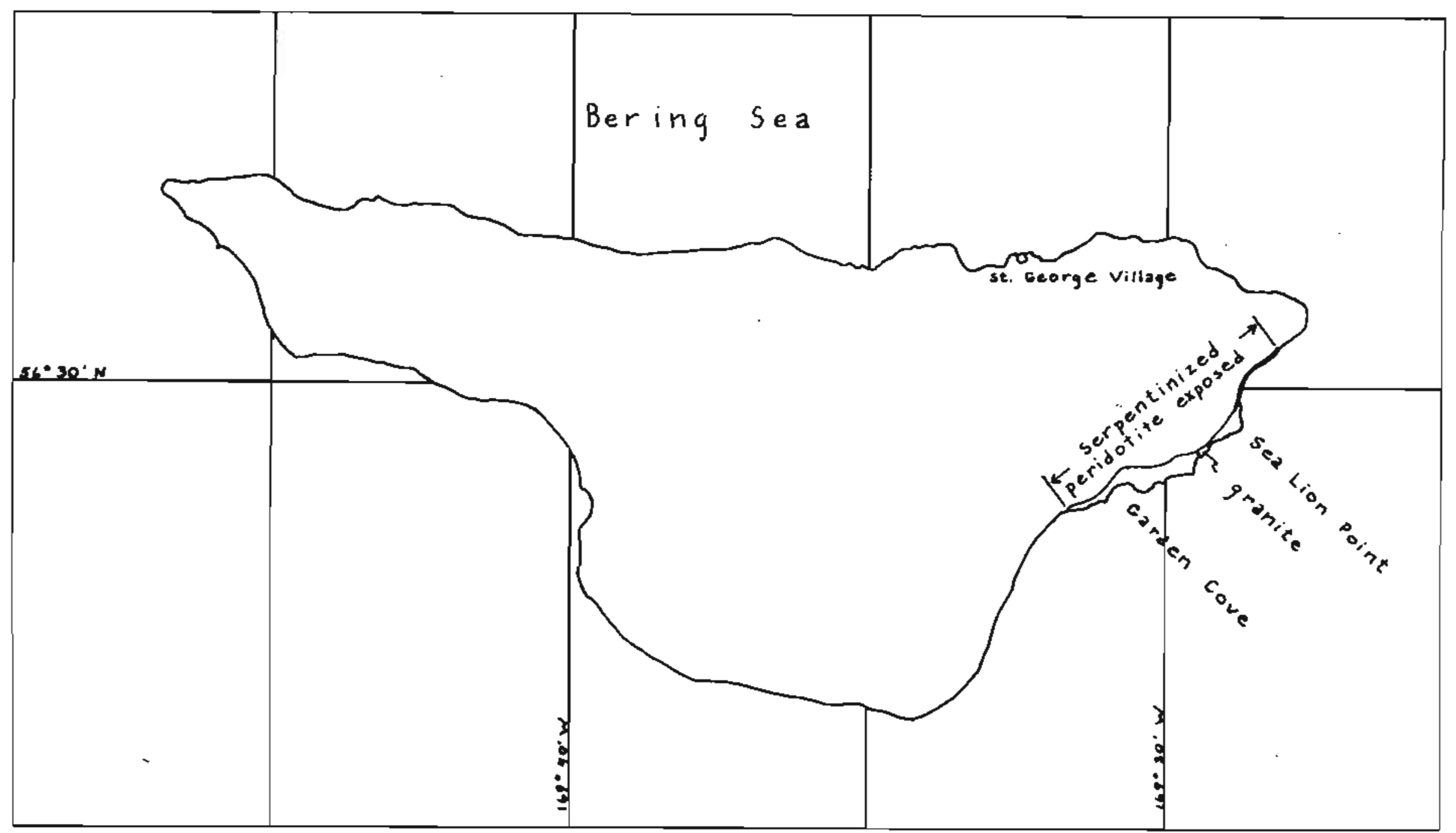

Fig. 2 Location of serpentinized peridotite and granite outcrops at base of cliffs on southeastern St. George Island 


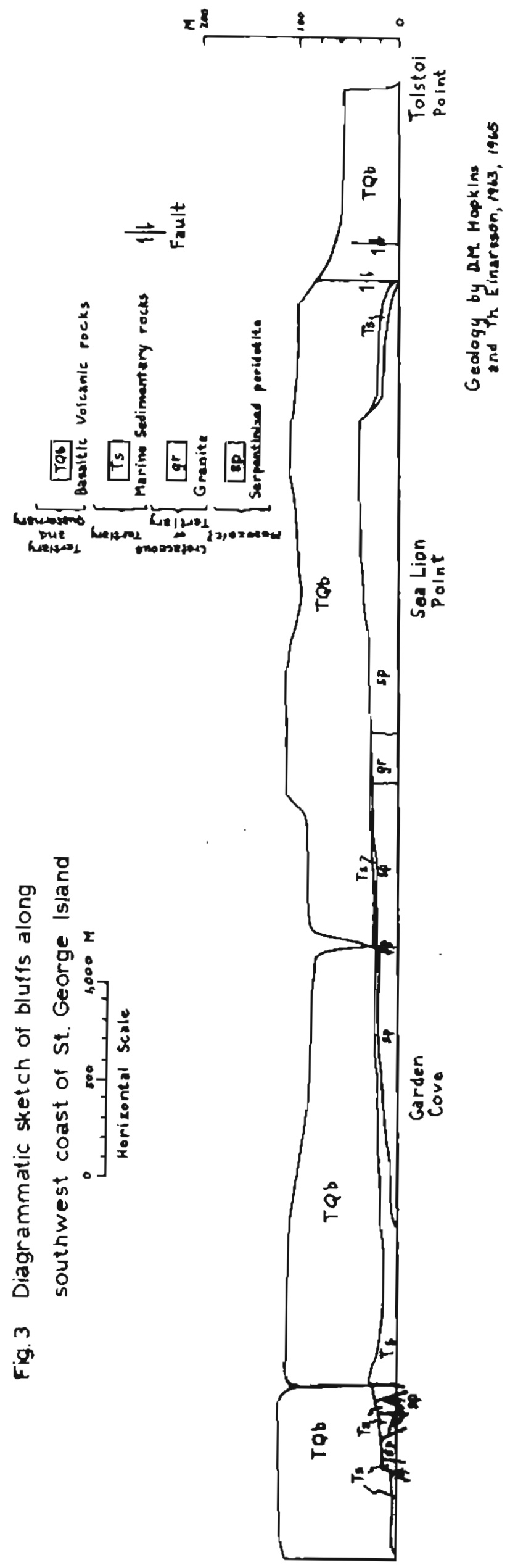




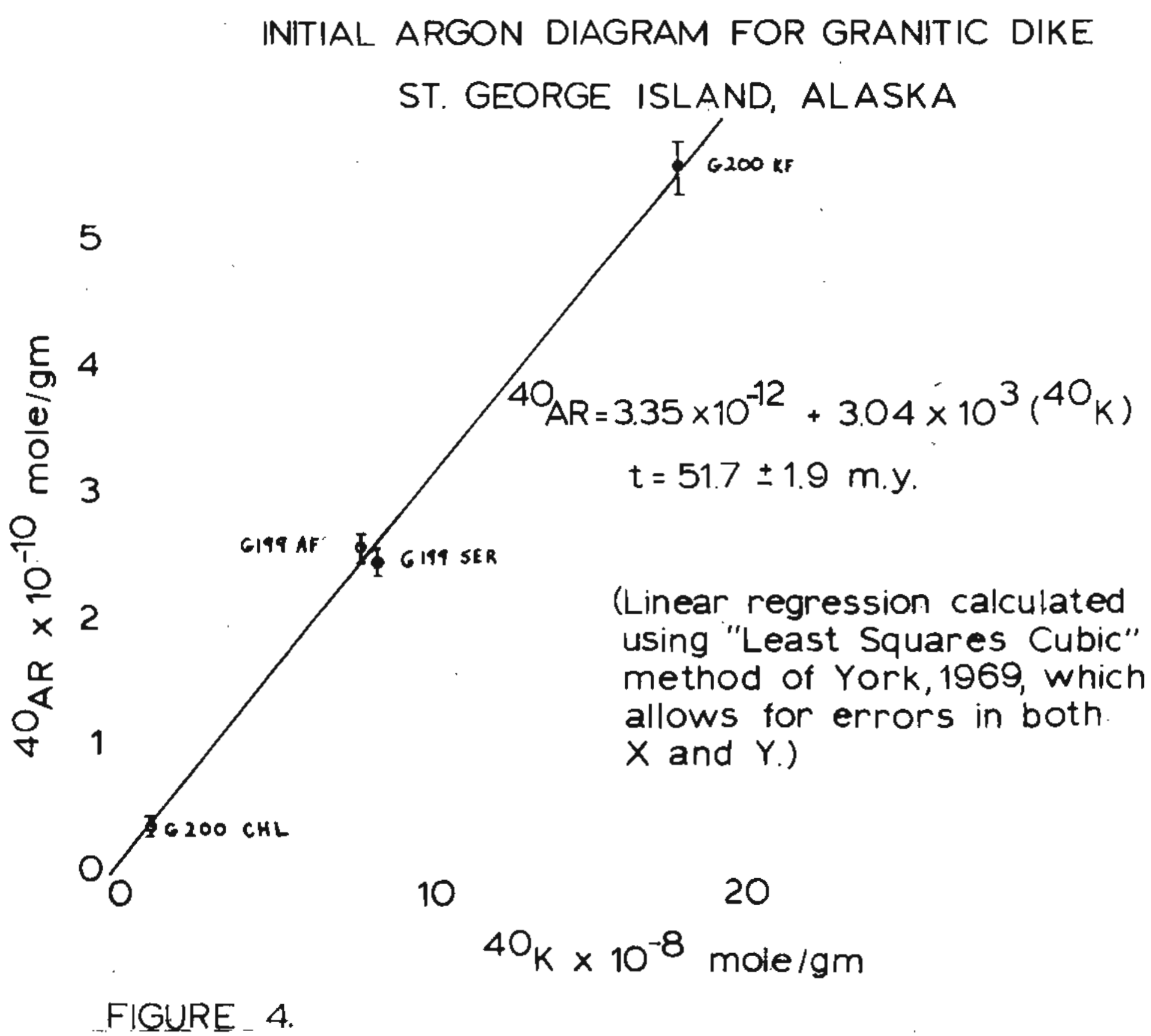




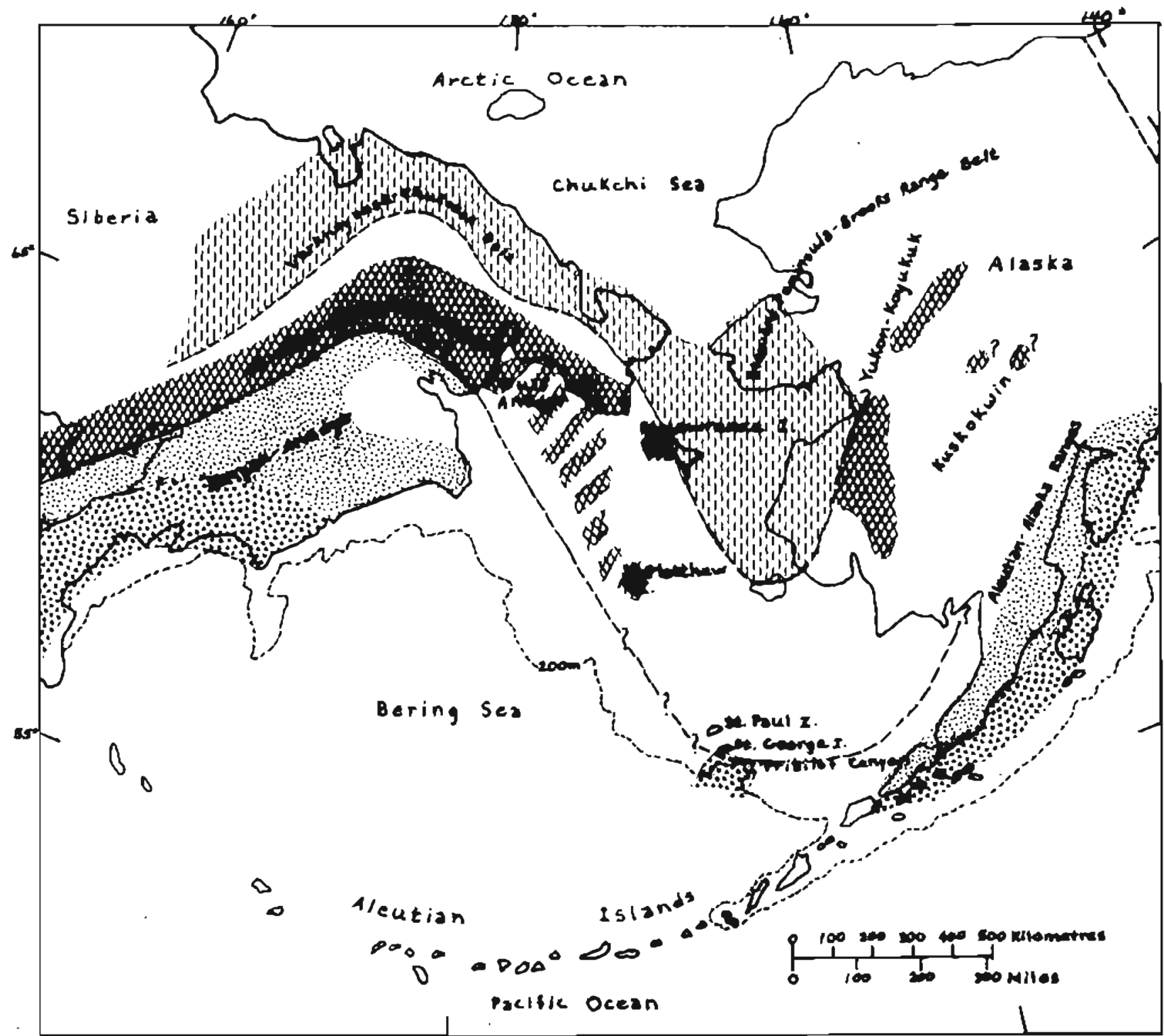

VOLCANIC ROCKS

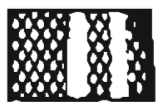

Broken pattern where extended across Bering shelf by goephysical interpretation
TERRIGENOUS DEPOSITS

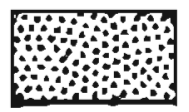

Deep water

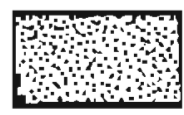

Shallow water and nonmarine
MIOGEOSYNCLINAL DEPOSITS

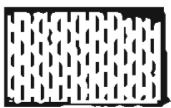

Chiefly pre-late

cretaceous

Fig. 5 Distribution of volcanism and terrigenous deposition in the Bering Sea region during Late Cretaceous and earliest Tertiary time $(\approx 80$ to $55 \mathrm{~m} . \mathrm{y}$. ago). Outer margin of Bering Sea shelf at 200-m contour shown by dashed line. After Patton and others, 1976; Marlowe and others, 1976. 